\title{
The Influence of Culture on Women's IT Career Choices
}

\author{
Andre P. Calitz ${ }^{(\varpi)}(\mathbb{D}$, Margaret Cullen (D), and Dudu Fani (D) \\ Department of Computing Sciences, \\ Nelson Mandela University, Port Elizabeth, South Africa \\ Andre. Calitz, Margaret. Cullen, \\ Duduetsang.Fani\}@Mandela.ac.za
}

\begin{abstract}
Skilled Information Technology (IT) professionals are essential to support businesses and the economy. Businesses increasingly require more qualified IT professionals, be they male or female. In South Africa, the number of women professionals participating in the IT industry is less than $20 \%$. A number of factors influence women's IT career choices, such as previous programming exposure, parents, teachers and role models. Research suggests that there are gender differences in preferences and beliefs that may affect career choices, including cultural influences. The role of culture in women's IT career decisions has not been extensively explored in South Africa. The aim of this exploratory study was to determine if the factor, Culture influences women's IT career choices in South Africa. An on-line survey was conducted amongst women IT professionals in South Africa to determine the factors that influenced their IT career choices. The data from the survey were analysed using Exploratory Factor Analysis. The results, specifically relating to the factor Culture, are reported in this paper. The findings indicate that the factor Culture plays an important role when women make IT career choices as well as when females decide to remain in an IT career. The study found that culture does play a significant role in IT career decisions for different ethnic groups in South Africa. The findings suggest that efforts must be made to educate young women in computational thinking and expose them to the many career opportunities available for women in the IT industry.
\end{abstract}

Keywords: Women in IT $\cdot$ Culture $\cdot$ IT career choices

\section{Introduction}

The IT industry has been a vital component in modern business evolution and has enabled sustained business operational success. Skilled IT professionals are an essential component for business success, however businesses are experiencing an IT skills shortage. The European Commission estimated that there will be approximately 500,000 vacant positions in all sectors of the economy for IT specialists by 2020 [15].

Worldwide, females are a large pool of participants in the workforce, with over half the global workforce being female [30]. However, in the IT industry there is a notable gender imbalance with fewer females participating in the workforce with a lesser number involved in technical leadership positions [12, 19, 28]. The OECD [28] report 
indicates that men are four times more likely than women to become IT specialists. In South Africa, the number of women professionals participating in the IT industry is less than $20 \%$ [26].

A number of factors influence young persons' career decisions. Sources of information and the impact of relatives, teachers and IT role-models have been highlighted as important career choice influencers [24]. A young person's intrinsic and extrinsic motivation, previous exposure to technology and specific programming, all strongly correlated with the decision to pursue a career in IT $[3,9]$.

Culture can also influence peoples' career decisions [16]. Culture is defined as the arts, customs and habits that characterise a certain society or nation. Culture includes the way the people in a society dress, the customs they practice in their marriages, the languages they speak, as well as their family lives, their work patterns, religious ceremonies and leisure pursuits [20]. Zimmermann [34] further describes culture as the beliefs, values and material objects that constitute a people's way of life. Culture is the characteristics and knowledge of a particular group of people encompassing language, religion, cuisine, social habits, music and arts [34]. Cultural factors that influence career choice include but are not limited to religion, personal relations, family responsibilities and attitudes towards networking [16].

The aim of this exploratory study is to determine the influence of culture on career decisions made by women working in the IT sector. This paper provides preliminary insights into the role of culture in career decisions by women working in the IT industry. The results highlight the importance of culture and the traditional roles bestowed on women. The layout of the paper is as follows: the research problem, research question and the Women in IT survey are discussed in Sect. 2. Literature on culture and the influence of culture on career decisions for women are discussed in Sect. 3. The Women in IT survey results are presented in Sect. 4. Conclusions and recommendations, relevant to young women wanting to choose a career in IT and future work are presented in Sect. 5.

\section{Literature Review}

The field of IT is one of the most evolving fields requiring expert skills. According to CareerJunction [8], IT is one of South Africa's top five employment sectors. Software Development is named as the most sought-after skill in the job market having grown by $12 \%$ from month to month during 2019. In addition, InformationWeek states that fastgrowing jobs are emerging in the tech space with many relating to artificial intelligence and machine learning [10]. CareerJunction [8] advertised 2872 IT jobs in South Africa and the IT jobs most in demand are software development and programming. South Africa is a developing country where IT skills are in high demand. These IT skills are not met by Higher Education Institutions' IT graduate numbers [14, 22].

In examining the contrasts of the genders participating in IT leadership positions, Rogers [30] noted that the number of women professionals involved in high ranking professional IT jobs was significantly lower compared to their male counterparts. Less than $15 \%$ of females are in leadership positions in the IT industry [26]. During the year 2014, technology companies that are IT industry drivers disclosed their staff 
demographics. Companies such as Google, revealed that only $17 \%$ of their IT staff were female, while Apple and Facebook had 20\% and 15\% respectively [5].

Careers in the field of Science, Technology, Engineering and Mathematics (STEM) have historically experienced low levels of representation from females [11, 24]. Study fields such as Medicine [11, 30] have achieved successes in recruiting more females to the profession than in the past, due to their early career education, focused training methods and research strategies that are designed to attract female participants to the profession. IT on the other hand, continues to lag behind and is experiencing the opposite, with decreasing numbers of women participants compared to earlier decades [23].

Career choices are made by young people during their early secondary school career [27]. This is a similar assertion made by Armstrong and Riemenschneider [4] who examined an earlier model by scholar Ahuja [2], which noted that the choice of a career in IT is made years before the individual starts working. The high school era is a critical time where young people are guided by their family, teachers, career counsellors and role models most influential to them, to choose school subjects that later direct them to future fields of study and careers.

Teachers who act as career counsellors have been noted to have a strong influence on the career choices of their scholars, however this advice has resulted in furthering the gender imbalance in IT. Adya and Kaiser [1] discovered that teachers were more likely to encourage girls towards traditionally female careers such as pre-primary teaching, nursing and secretarial work and males towards technical careers [24]. This is due to their own limited perspectives, societal biases with partial information of the profession of IT and other career options. Cultural factors also influence career choice and include but are not limited to religion, personal relations, frame of reference and attitudes towards networking among others [16].

\subsection{Women in IT}

Although women outnumber men in terms of enrolment in higher learning institutions, when it comes to technology-based degrees, men dominate. The number of women obtaining degrees in computer and information systems continues to decrease while the number of women in law school, medical school and other STEM fields gradually increases [21]. The major influences that Jung et al. [21] identified were the influence of marketing, media portrayal of women in technology, role models, social encouragement and education impact.

Factors influencing the career choices of scholars according to Snyman [32] are self-efficacy, outcome expectations, goal representations, interest and sources of advice, financial expectations and the gender gap. The gender gap particularly identifies factors that influence women. Seeing women working in the technical field and female IT role models also influences girls when deciding on their careers [32]. It is important for children to have access to and use computers at home and in schools [21]. Parental support is another influential factor on whether women choose a technology related major. Researchers have highlighted the important role of parents, specifically the role the father plays in the children's career choices $[9,31]$. 
High performance in school in problem solving subjects like mathematics is linked to increased self-confidence. Women who opt for a successful career in IT have been noted to be those who experimented with technology and viewed themselves early in life as capable. By choosing this career path, women often want to engage with their skills, grow through promotional opportunities and have the ability to reach top management levels. Women who have opted for IT find the salaries, future status and lifestyle attractive features of a career in IT [31]. Women with STEM degrees were noted to earn more than their peers who opted for other degrees and had projected job growth of $17 \%$ compared to $9.8 \%$ of those in non-STEM degrees [7].

Great lengths have been taken by society and families to attract and encourage young high school scholars of all genders to enter professional careers due to increased status for the family [5, 33]. The careers include doctors, accountants and lawyers. However IT, whilst misunderstood as a profession by society and families at large, is seen and respected as a smart profession often reserved for technical males [9, 25].

The lack of prominent female IT role models influences societal views on the profession. Culturally, females have not been socialised to view the field of IT as an important field of study. Pretorius and De Villiers [29] revealed that $66 \%$ of females in South Africa view the field of IT as cold with great emphasis on functional, abstract, procedural and task-oriented characteristics. They associate IT as mainly concerned with programming and building hardware.

Male dominance and the results of one-sided involvement in the IT field can be seen in the entertainment industry of gaming where technology has been used to develop recreational games. These games largely cater for the male population thus possibly reducing the potential profits that could be earned from involving female participants. Games are not being used as a tool to raise interest in technology in females [1]. The use of video games was noted by Main and Schimpf [23] as a contributing factor to computer biases. Access to games arouses technical interest, improves skills, such as design and rotational abilities and thus serves as an entry to the IT field and is a promoter of interest as it develops skills such as graphic design in participants.

\subsection{Culture and Societal Attitudes Regarding Family}

Females are often noted to have strong societal ties to family units, religion and cultural activities and thus participation in a career often hinges on the support from these communities and the ability to continue with the associated activities with these groups [23, 29]. Du Bow [13] outlined that even though high achieving females outnumber males in the mathematics field, the under-representation of women in IT reflects social, cultural and family thinking [31]. While women live in modern times, the traditional family structure has not changed. Women continue to be the primary care givers of families. Pretorius and De Villiers [29] observed that women battle to balance a demanding IT job while still being heavily involved at home.

Family influence is the reason for the high volume of females participating in the IT field in Mauritius, as the family and national culture encourage females to view IT as a potentially viable career [29]. Over 53\% of Computer Science enrolments in Mauritius in 2011 were women. This is a similar situation in the Indian society, where the family 
structure supports the idea of women actively choosing the IT field as a career of choice. In societies such as India and the Soviet Union, women participate in IT careers in higher numbers when compared to men [17].

In South Africa, this reality is different as women view themselves according to traditional society's expectations, which emphasise women as homemakers before being viewed as career women. Adya and Kaiser [1] concurred that females who opt for IT have been noted to come from families where the parents are highly educated. The influence of parents with degrees allows the family structure to choose nontraditional careers where success is highly valued.

\section{Research Design}

Women are under-represented in the South African IT industry with only $17 \%$ of women pursuing careers in the IT sector [14]. A higher percentage of males graduate with IT qualifications from universities and colleges than women [14]. Scholars making career choices are influenced by parents, role models, society and the educational system. It has been shown that culture does play a role in the career choices women make worldwide [16]. The research problem addressed in this study is that many young South African women (female scholars) do not consider a career in IT, possibly as a result of cultural influences. The research question addressed in this study is: Does the factor Culture influence women IT professionals' IT career choices?

A questionnaire was compiled from a combination of similar questionnaires used in previous gender based studies and from literature [13, 29]. An anonymous survey was conducted and the questionnaire included both closed and open-ended questions. The questionnaire was divided into two sections consisting of demographic information and items relating to the independent factors. A five-point Likert rating scale $(1=$ Strongly disagree to $5=$ Strongly agree) was used to gather information from respondents regarding the factors that led them to choose a career in IT and to stay in the IT profession.

The Institute of Information Technology Professionals South Africa (IITPSA) represents IT professionals in South Africa. IITPSA has over 10000 members including over 1700 female members. The request to participate in the study was sent to the female members. In addition, the questionnaire was sent to the Computer Science and Information Systems Alumni of three S.A. universities. The questionnaire was captured using the Nelson Mandela University on-line survey tool, QuestionPro. The data were statistically analysed using Statistica. The following hypotheses relating to culture were tested in this study:

- $\mathrm{HO}_{1}$ : Culture and societal attitudes regarding an IT career exert no influence on females opting for a career in IT.

- $\mathrm{HA}_{1}$ : Culture and societal attitudes regarding an IT career positively influence females on opting for a career in IT.

- $\mathrm{HO}_{2}$ : Culture and societal attitudes regarding IT career exert no influence on females remaining in the field of IT. 
- $\mathrm{HA}_{2}$ : Culture and societal attitudes regarding IT career positively influence females remaining in the field of IT.

A conceptual model was designed to test the various factors that contribute to participation levels. The independent variable was culture and the two dependant variables were Females opting for an IT career and Females remaining in an IT career. The model to test the factor Culture is demonstrated in Fig. 1.

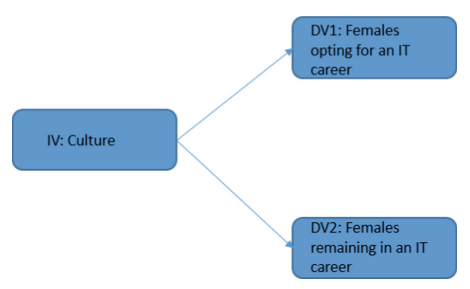

Fig. 1. Proposed conceptual model

The items for the factor Culture were obtained from a literature study [13, 16, 29]. The items relating to the independent factor Culture were as follows:

- An IT career is respected in my community;

- In my culture, IT is not seen as a career for women;

- In my culture, people have a clear understanding of IT;

- In my culture, people have a clear understanding of IT careers;

- In my community, people are familiar with IT careers;

- In my culture, having a large family is important; and

- In my culture, a woman is expected to have a family and children.

The two dependent factors with 12 items were:

(1) Females opting for an IT career; and

(2) Females remaining in an IT career.

\subsection{Theory of Reasoned Action}

Decisions to choose and persist in a career or to change careers, are made from adolescence to middle age and are influenced by a number of factors. These factors may be internal to the individual, such as interests or skills, or external, such as influences by families, the economy, or even certain policies [18]. An important theory that relates to career choices is the theory of reasoned action (TRA) by Azjen and Fishbein [6], which states that an individual's behavioural intention is influenced by his/her own attitude and the social subjective norms prevalent in their environment. This theory is derived from the expectancy theory, which indicates that motivation for career decision is the result of the individual's belief in future possible outcomes. The theory of reasoned action stresses that an individual's behaviour can be examined and predicted through the examination of their underlying basic motivation. Thus, voluntary 
decisions of women, such as career choices can be predicted based on their respective attitude and the influence of those in their social circle and in this case culture [18].

\section{Women in IT Culture Survey Results}

The survey was completed by 93 respondents after three calls for participation. The marital status of the female respondents (Fig. 2) indicated that out of 90 responses, $9 \%$ $(\mathrm{n}=8)$ were divorced, $10 \%(\mathrm{n}=9)$ living together, $51 \%(\mathrm{n}=46)$ were married, $29 \%$ $(n=26)$ were single and one widowed. The respondents indicated that $44 \%(n=40)$ did not have any children, $49 \%(n=44)$ had one to two children, while $7 \%(n=6)$ had three or more. The Age responses (Fig. 3) showed that $29 \%(n=26)$ were twenty one to twenty nine years old, $33 \%(\mathrm{n}=29)$ were thirty to thirty nine years old, $24 \%$ $(\mathrm{n}=21)$ were forty to forty nine years old, $15 \%(\mathrm{n}=13)$ were fifty to fifty-nine years old. There was no one older than sixty. The majority of the women were White $55 \%$ $(\mathrm{n}=49)$, followed by Africans $26 \%(\mathrm{n}=23)$, and the rest are $11 \%(\mathrm{n}=10)$ Coloured, $6 \%(\mathrm{n}=5)$ Indian and 2\% $(\mathrm{n}=2)$ did not discloses their ethnicity (Fig. 4).

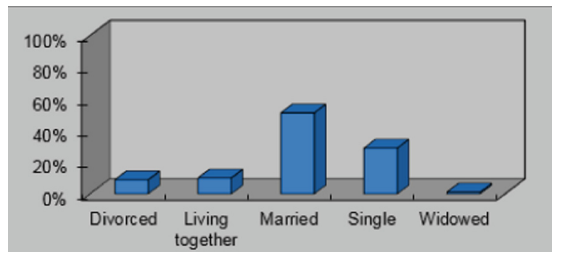

Fig. 2. Marital status

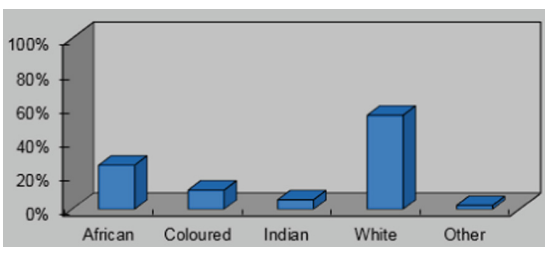

Fig. 4. Ethnicity

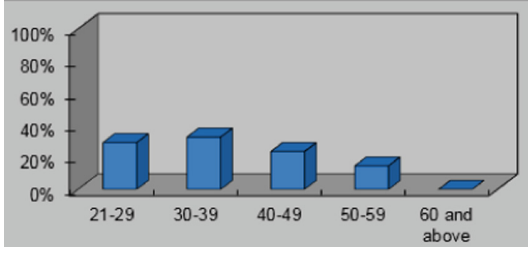

Fig. 3. Age

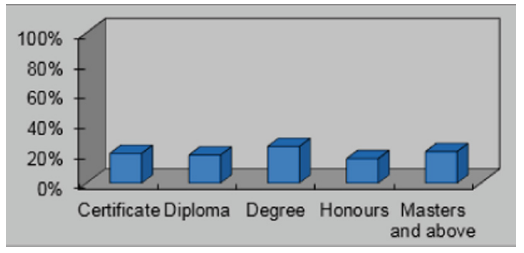

Fig. 5. Highest IT qualification

The highest IT qualification indicated (Fig. 5) by respondents were that $20 \%$ $(\mathrm{n}=17)$ had Certificates, 19\% $(\mathrm{n}=16)$ had Diplomas, 24\% $(\mathrm{n}=21)$ had Degrees, $16 \%(\mathrm{n}=14)$ had Honours degrees and $21 \%(\mathrm{n}=18)$ had a Masters degree or above. Twenty percent $(n=18)$ had zero to two years of IT work experience, $8 \%(n=7)$ had three to four years experience, $26 \%(\mathrm{n}=23)$ had five to nine years experience, $21 \%$ $(n=19)$ had ten to nineteen years experience, $25 \%(n=22)$ had more that 20 years experience. Twenty nine percent $(n=26)$ indicated that they had role models when they started their career. 
The five point Likert scale responses to the items below are reported by combining the results for Strongly Disagree/Disagree, as well as for Agree/Strongly agree.

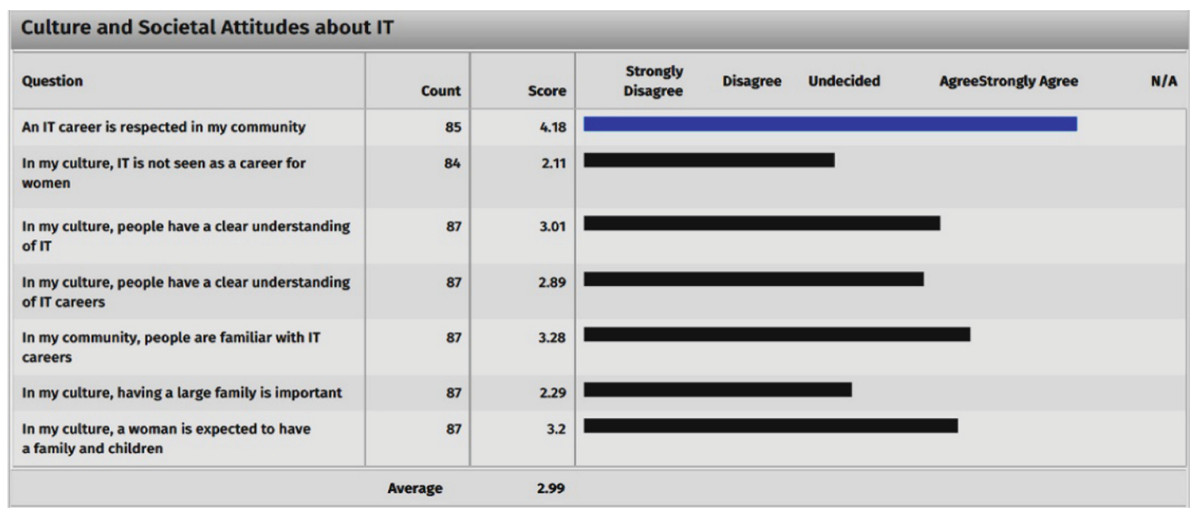

Fig. 6. Culture and societal attitudes about IT

Mixed responses were received pertaining to culture and societal attitudes about IT (Fig. 6). Eighty eight percent $(\mathrm{n}=60)$ of the respondents agreed that a career in IT was respected in the community. In contrast, sixty-nine percent $(n=47)$ did not agree with the statement that culturally IT was not seen as a career for women, thus implying that culturally IT was seen as a career for women. A mixed response to the statement that people in their respective cultures had a clear understanding of IT was made with $41 \%$ $(n=29)$ disagreeing, $36 \%$ agreeing while $23 \%$ were neutral regarding the statement. Fifty one percent $(n=36)$ disagreed that people in their cultures had a clear understanding of IT careers, $50 \%(\mathrm{n}=35)$ agreed that their community was familiar with careers in IT. When it came to societal and cultural perception of females, $71 \%$ $(\mathrm{n}=50)$ disagreed that in their cultures having a large family was important and $58 \%$ $(\mathrm{n}=41)$ agreed that in their culture a woman is expected to have a family and children. These findings are supported by the EFA results presented below.

The Cronbach alpha for the items for the factor Culture was $0.88(n=90)$ indicating 'excellent reliability'. The correlations were statistically significant at 0.05 level for $\mathrm{n}$ ranging from 71 to 55 if $|\mathrm{r}| \geq$ rcrit ranging from .234 to .266 and practically significant if $|r| \geq .300$. In Table 1 , the null hypothesis was accepted $\left(\mathrm{HO}_{1}\right)$ indicating that Culture and societal attitudes regarding an IT career exert no influence on females opting for a career in IT. The alternative hypothesis was accepted indicating that Culture and societal attitudes regarding IT career positively influence females remaining in the field of IT. 
Table 1. Correlations

\begin{tabular}{l|l|l|l|l}
\hline & Hypotheses & $\begin{array}{l}\text { Pearson } \\
\text { correlations }\end{array}$ & $\begin{array}{l}\text { Correlation } \\
\text { strength }\end{array}$ & $\begin{array}{l}\text { Accepted } \\
\text { or } \\
\text { rejected }\end{array}$ \\
\hline $\mathrm{H} 0_{1}$ & $\begin{array}{l}\text { 'Culture and societal attitudes } \\
\text { regarding an IT career' exert no } \\
\text { influence on females opting for a career } \\
\text { in IT }\end{array}$ & 0.094 & $\begin{array}{l}\text { Low } \\
\text { positive }\end{array}$ & Accepted \\
\hline $\mathrm{HA}_{2}$ & $\begin{array}{l}\text { 'Culture and societal attitudes } \\
\text { regarding IT career' positively } \\
\text { influence females remaining in the field } \\
\text { of IT }\end{array}$ & 0.427 & $\begin{array}{l}\text { Large } \\
\text { positive }\end{array}$ & Accepted \\
\hline
\end{tabular}

The Exploratory Factor Analysis (EFA) for the factor Culture indicated that one item had to be deleted and three items reversed (Table 2). The six remaining items explained $70 \%$ of the total variance for this factor.

Table 2. EFA remaining items for the factor: culture

\begin{tabular}{|c|c|}
\hline \multicolumn{2}{|l|}{ Culture and Societal Attitudes about IT } \\
\hline Cul.04 In my culture, people have a clear understanding of IT careers & .936 \\
\hline Cul.03 In my culture, people have a clear understanding of IT & .913 \\
\hline Cul.05 In my community, people are familiar with IT careers & .839 \\
\hline Cul.01 An IT career is respected in my community & .580 \\
\hline $\begin{array}{l}\text { Cul.07* In my culture, a woman is expected to have a family and } \\
\text { children`REVERSED } \\
\text { In my culture, a woman is not expected to have a family and children }\end{array}$ & .826 \\
\hline $\begin{array}{c}\text { Cul.06* In my culture, having a large family is important *REVERSED } \\
\text { In my culture, having a large family is not important }\end{array}$ & .770 \\
\hline $\begin{array}{l}\text { Cul.02* In my culture, IT is not seen as a career for women*REVERSED } \\
\text { In my culture, IT is seen as a career for women }\end{array}$ & .670 \\
\hline $\begin{array}{l}\text { Minimum loading deemed significant }=.649 ; \\
\text { Percentage of Total Variance Explained }=70.0 \%\end{array}$ & \\
\hline
\end{tabular}

The t-test conducted with two categories and one-way ANOVA for the demographic variables with three or more categories indicated no statistical difference between Culture and the demographic variables marital status, age and number of children for different groups. The demographic variable Ethnicity, however indicated a statistical difference $(\mathrm{p}=0.004)$ between the groups African/Coloured/Indian and White, with a medium practical statistical difference (Cohen's $d=0.73$ ) for the factor Culture (Table 3). 
Table 3. Ethnicity t-test

\begin{tabular}{|l|l|c|c|c|c|c|c|c|c|}
\hline Culture & African/Coloured/ndian & 34 & 3.11 & 0.91 & -0.66 & -3.02 & 66 & .004 & 0.73 \\
& White & 34 & 3.77 & 0.90 & & & & & Medium \\
\hline
\end{tabular}

The demographic variable Highest Qualification, further indicated a statistical difference $(\mathrm{p}=0.046)$ between the highest qualifications Diploma/Degree and Honours/Masters and above with a medium practical statistical difference (Cohen's $\mathrm{d}=0.51$ ) for the factor Culture (Table 4). No statistical differences were recorded for the demographical variables IT Work experience and Role models.

Table 4. Highest IT qualification t-test

\begin{tabular}{|l|l|c|c|c|c|c|c|c|c|}
\hline Culture & Diploma/Degree & 30 & 3.66 & 0.87 & 0.46 & 2.03 & 62 & .046 & 0.51 \\
& Honours/Masters and above & 34 & 3.19 & 0.95 & & & & & Medium \\
\hline
\end{tabular}

\section{Conclusions and Future Research}

The theory of reasoned action indicates that voluntary decisions of women such as career choices can be predicted based on their respective attitude and the influence of those in their social circle and in this case, culture [18]. In formative years, the influence of others is important, specifically the father [9, 31]. A young person's preferences may be influenced by the perceptions of those in their culture. This study contributes to the TRA theory as the subjective norms, included in the TRA model, which reflect the perception of how others think an individual should behave [6] are evident in this study's findings.

Societal gender stereotypes and social norms regarding careers and specifically IT, limit the number of females attracted to and staying in the IT profession [28]. Women, in general are less informed about the content of the work in IT, however they are informed about the inequalities in the field [19, 23]. The findings of this study indicate that although IT is noted as not being understood in the community $(41 \%, \mathrm{n}=29)$, it is seen as a respectable profession in society $(88 \%, \mathrm{n}=60)$. The Pearson correlation analysis confirmed that Culture and societal attitudes regarding an IT career exert no influence on females opting for a career in IT and that Culture and societal attitudes regarding IT career positively influence females remaining in the field of IT.

An important finding in this study (Table 3) indicates that for the two ethnic groupings, African/Coloured/Indian and White, the respondents perceived the influence of culture on an IT career choice statistically differently. Thus, the ethnic groups of African, Coloured and Indian women working in the IT industry perceive that culture does play a statistical significant role in women's IT career choices. These findings 
support Gathungu and Mwangi [16] that culture does influence women's career choice. Additionally, a statistical difference (Table 4) was also observed between the undergraduate vs the post-graduate degree groups regarding their perceptions on the role of culture in women's IT career choices.

This exploratory study has provided the foundation for evaluating Woman in IT career choices in South Africa and the influence of the factor Culture on the career choices and remaining in the IT industry. Future research will investigate the role of culture in women's IT career choices in more detail, by obtaining a larger sample size and evaluating the views of men as well. The study will be extended internationally and compare the South African results with other countries.

\section{References}

1. Adya, M., Kaiser, K.: Early determinants of women in the IT work-force: a model of girl's career choices. Inf. Technol. People 18(3), 230-259 (2005). https://doi.org/10.1108/ 09593840510615860

2. Ahuja, M.K.: Women in the information technology profession: a literature review, synthesis and research agenda. Eur. J. Inf. Syst. 11, 20-34 (2002). https://doi.org/10.1057/palgrave. ejis. 3000417

3. Aivaloglou, E., Hermans, F.: Early programming education and career orientation: the effects of gender, self-efficacy, motivation and stereotypes. In: SIGCSE 2019, Minneapolis, MN, USA, 27 February-2 March 2019 (2019). https://doi.org/10.1145/3287324.3287358

4. Armstrong, D.J., Riemenschneider, C.K.: The barriers facing women in the information technology profession: an exploratory investigation of Ahuja's model. In: SIGSIM-CPR 2014, Singapore, 29-31 May 2014, pp. 85-96 (2014). https://doi.org/10.1145/2599990. 2600006

5. Appianing, J., Van Eck, R.: Gender differences in college students' perceptions of technology-related jobs in computer science. Int. J. Gend. Sci. Technol. 7(1), 28-56 (2015)

6. Azjen, I., Fishbein, M.: Understanding Attitudes and Predicting Social Behaviour. Prentice Hall, New Jersey (1980)

7. Boedeker, P., Capraro, M., Capraro, R., Nite, S.: Women in STEM: the impact of STEM PBL implementation on performance, attrition and course choice of women. In: 2015 IEEE Frontiers in Education Conference (FIE), El Paso, TX, USA, 21-24 October 2015 (2015). https://doi.org/10.1109/fie.2015.7344178

8. CareerJunction: South Africa's Most In-Demand Skills (Executive Summary) (2019). http:// cj-marketing.s3.amazonaws.com/CJI_Executive_Summary.pdf

9. Collain, M., Trytten, D.: "You don't have to be a white male that was learning how to program since he was five:" computer use and interest from childhood to a computing degree. In: 50th ACM Technical Symposium on Computer Science Education (SIGCSE 2019), Minneapolis, MN, USA, 27 February-2 March 2019 (2019). https://doi.org/10.1145/ 3287324.3287383

10. Davis, J.: 6 Top Emerging Technology Jobs for 2019. InformationWeek (2019). https:// www.informationweek.com/strategic-cio/team-building-and-staffing/6-top-emergingtechnology-jobs-for-2019/d/d-id/1333522

11. Diekman, A., Brown, E., Johnston, A., Clark, E.: Seeking congruity between goals and roles: a new look at why women opt out of science, technology engineering and mathematics careers. Assoc. Psychol. Sci. 21(8), 1051-1057 (2010) 
12. Drury, M.: Women technology leaders: gender issues in higher education information technology. NASPA J. About Women High. Educ. 4(1), 96-123 (2011)

13. Du Bow, W.: Attracting and retaining women in computing. IEEE Comput. Soc. 14, 90-93 (2014)

14. Esterhuyse, A., Calitz, A.P., Cullen, M.: Post-graduate CS and IS students' career awareness. In: SACLA 2019 Conference, Drakensberg, South Africa, 15-17 July 2019 (2019)

15. European Commission: Digital Skills \& Jobs (2019). https://ec.europa.eu/digital-singlemarket/en/policies/digital-skills

16. Gathungu, J.M., Mwangi, P.W.: Entrepreneurial intention, culture, gender and new venture creation: critical review. Int. J. Bus. Soc. Res. (IJBSR) 4(2), 112-132 (2014). https://doi.org/ 10.18533/ijbsr.v4i2.402

17. Gharibyan, H., Gunsaulus, S.: Gender gap in computer science does not exist in one former soviet republic: results of a study. In: Proceedings of 11th SIGCSE Conference on Innovation and Technology in Computer Science Education, vol. 1, pp. 222-226 (2006)

18. Govender, I., Khumalo, S.: Reasoned action analysis theory as a vehicle to explore female students intention to major in information systems. J. Commun. 5(1), 35-44 (2014)

19. Hyrynsalmi, S.M.: The underrepresentation of women in the software industry: thoughts from career-changing women. In: Proceedings of the 2nd International Workshop on Gender Equality in Software Engineering, Montreal, Quebec, Canada (2019). https://doi.org/10. 1109/ge.2019.00008

20. Itulua-Abumere, F.: Sociological concepts of culture and identity, pp. 1-5 (2014). www. Flourishabumere.com

21. Jung, L., Clark, U., Patterson, L., Pence, T.: Closing the gender gap in the technology major. Inf. Syst. Educ. J. 15(1), 26-41 (2017)

22. Kirlidog, M., van der Vyer, C., Zeeman, M., Coetzee, W.: Unfulfilled need: reasons for insufficient ICT skills in South Africa. Inf. Dev. 34(1), 5-19 (2018). https://doi.org/10.1177/ 0266666916671984

23. Main, J., Schimpf, C.: The underrepresentation of women in computing fields: a synthetic of literature using a life course perspective. IEEE Trans. Educ. 60, 1-10 (2017). https://doi.org/ 10.1109/TE.2017.2704060

24. Mbilini, S.N., le Roux, D.B., Parry, D.A.: Does automation influence career decisions among South African students? In: SAICSIT 2019 Conference, Skukuza, South Africa, 1718 September 2019 (2019). doi.org/10.1145/3351108.3351137

25. McKinney, V., Wilson, D., Brooks, N., O’Leary-Kelly, A., Hardgrave, B.: Women and men in the IT profession. Commun. ACM 51(2), 81-84 (2008). https://doi.org/10.1145/1314215. 1314229

26. Muro, C., Gabriel, M.: Women engagement in ICT professions in Tanzania: exploring challenges and opportunities. Int. J. Comput. Inf. Technol. 5(5), 443-447 (2016)

27. Njoki, M.M., Wabwoba, F., Micheni, E.J.: ICT definition implication on ICT career choice and exclusion among women. Inf. Technol. Comput. Sci. 5, 62-71 (2016)

28. OECD: Bridging the Digital Gender Divide (2018). http://www.oecd.org/internet/bridgingthe-digital-gender-divide.pdf

29. Pretorius, H., De Villiers, C.A.: South African perspective of the international discourse about women in information technology. In: SAICSIT 2010 Conference, Bela, South Africa, 11-13 October 2010, pp. 265-274 (2010). https://doi.org/10.1145/1899503.1899533

30. Rogers, V.L.N.: Women in IT: the endangered gender. In: Proceeding of the 2015 ACM Annual Conference on SIGUCCS, pp. 95-98 (2015). https://doi.org/10.1145/2815546. 2815558

31. Sharif, N., Ahmed, N., Sarwar, S.: Factors influencing career choices. IBT J. Bus. Stud. 15 (1), 33-45 (2019) 
32. Snyman, M.: South African scholar ICT career choice model. Unpublished Honours study. Department of Computing Sciences, Nelson Mandela University, South Africa (2012)

33. Vitores, A., Gil-Juarez, A.: The trouble with 'women in computing': a critical examination of the deployment of research on the gender gap in computer science. J. Gend. Stud. 25(6), 666-680 (2016). https://doi.org/10.1080/09589236.2015.1087309

34. Zimmermann, K.: What is culture? Live Science (2017). https://www.livescience.Com/ 21478-what-is-culture-definition-of-culture.html 